\title{
Educational social networking services: The case of edmodo in the teaching practice
}

\author{
Nafsika Tegousi ${ }^{1}$ and Vasileios Drakopoulos ${ }^{2 *}$ \\ ${ }^{1} \mathrm{PhD}$ Candidate, Department of Computer Science and Biomedical Informatics, University of Thessaly, \\ Greece
}

Received: 19 September, 2020

Accepted: 29 October, 2020

Published: 30 October, 2020

*Corresponding author: Vasileios Drakopoulos, Assistant Professor, Department of Computer Science and Biomedical Informatics, University of Thessaly, Greece, E-mail:vdrakop@uth.gr

Keywords: Computational science; Social learning network; Interaction; Social networking service; Information literacy; Programme of study or curriculum; ICT

https://www.peertechz.com

\section{Check for updates}

${ }^{2}$ Assistant Professor, Department of Computer Science and Biomedical Informatics, University of

Thessaly, Greece

\section{Abstract}

In recent years, there has been a strong education interest in second generation World Wide Web (Web 2.0) applications such as blogs, social networking, information sharing tools, social bookmarking and more. This article presents a case of using an online social learning network offering communication, collaboration and coaching tools to K-12 schools and teachers as well as a means of communication among pupils themselves. Given the students' familiarity with computers and the internet, it was considered that using these tools in teaching would motivate them during the lesson, and, in particular, it would benefit the weakest students who often maintain a non-positive attitude towards the traditional (conventional) face-to-face lesson. In order to achieve this goal, Edmodo has been selected from all the available as a technology based educational learning tool, thanks to the ability of using the Greek language since the summer of 2011 . The features of this social learning tool and the experience of using it in Secondary Education within the course "Informatics Applications" are reported here: during one school year, and some examples of its use in everyday teaching. The advantages of using it both pedagogically and practically, as well as some problems encountered by students and teachers during their practicum studies, are presented. The purpose of this article is to present in general terms the use of the Edmodo platform in the course of Informatics in a real class of the Evening Vocational Lyceum (EPAL).

\section{Introduction}

An online social learning network is a social network that involves members of the education community (teachers, pupils, school advisors, etc.). Through this network members exchange information, material, ideas and opinions while they can focus on specialised education subjects and interests [1]. In an effort to avoid the issues arising from the improper use of social media, secure social networking environments have been developed to offer education opportunities.

This article refers to the use of Edmodo as a supportive tool for the educational process in Secondary Education. The aim of the work is to present an online educational social network in the environment of Edmodo as it was used in the teaching of the course "Informatics Applications" during one school year. This action took place during the 2015-2016 school year in the 1st grade of the Evening Vocational Lyceum (EPAL) and the main tool used was Edmodo. At the same time, the reasons that led to the search for such a tool and the choice of the specific one as well as the assessments reached by the teachers, students and parents who used it in order to be used in the future teaching not only of the Informatics course but also other courses are presented.

\section{Materials and methods}

\section{The application used}

\section{What it is}

Edmodo is a tool that provides a restricted environment in which teachers and students enroll in digital classes and, by using their personal codes, communicate, interact, collaborate, and exchange educational material within structured or non-pedagogical activities [2-3]. Moreover, Edmodo's digital platform also gathers a large number of users from education and is a social networking environment in which the participation of teachers and pupils involves the creation 
of a user account through which they can quickly publish their texts, notes, comments and thoughts. At the same time, they can send unlimited messages to each other and form groups according to the model of Google's teams [4]. Of course in this platform there is the ability to search for other teachers or pupils. At this point it should be stressed that the platform environment is completely secure for users. Their participation is ensured through sending a relevant request, which the recipient evaluates and accordingly informs the sender of a personal code which the sender uses to have access to the group.

\section{What it offers}

The main features of the tool are: Teachers have full supervisory control as well as the ability to create teams for each of their classes and supervise the development of their activities separately. At the same time, they can communicate with parents and inform them of important issues, and even add their colleagues to their contacts to exchange ideas and experiences.

- The process of making one page is simple. All you need is an e-mail address to complete the registration. Then you will need some time to create your classes (Figure 1).The use of Edmodo combines education and entertainment, because through this secure environment students can: a) cooperate with each other by exchanging material and information, b) have fun exchanging posts [5] .

- Organizing the teacher's wall, by subject for easier reference.

- Monitoring the current activity of a specific member of the group, the other members of the group, as well as managing a member's messages (selection, deletion, processing).

- Search and link between teachers or classes .

- Teacher's participation in communities to share resources (Figure 2),

- Creating groups and sub-groups for easier department interaction and more effective teamwork.

- Control of announcements in a short time [6].

\section{Teaching with edmodo in secondary education}

The course of the subject: The experience, presented in this article by the use of Edmodo in the classroom concerns the teaching of the course "Informatics Applications" in the first class of an Evening Vocational Lyceum (EPAL).

In an effort to set up a module on the use of cloud applications which are offered on the Internet to create document management and collaborate remotely, Edmodo has been a powerful Education Social Networking service that helped the teacher to cope with daily problems. The ability to use worksheets in an electronic form, storage and retrieval of students' work so that they can be evaluated from home,

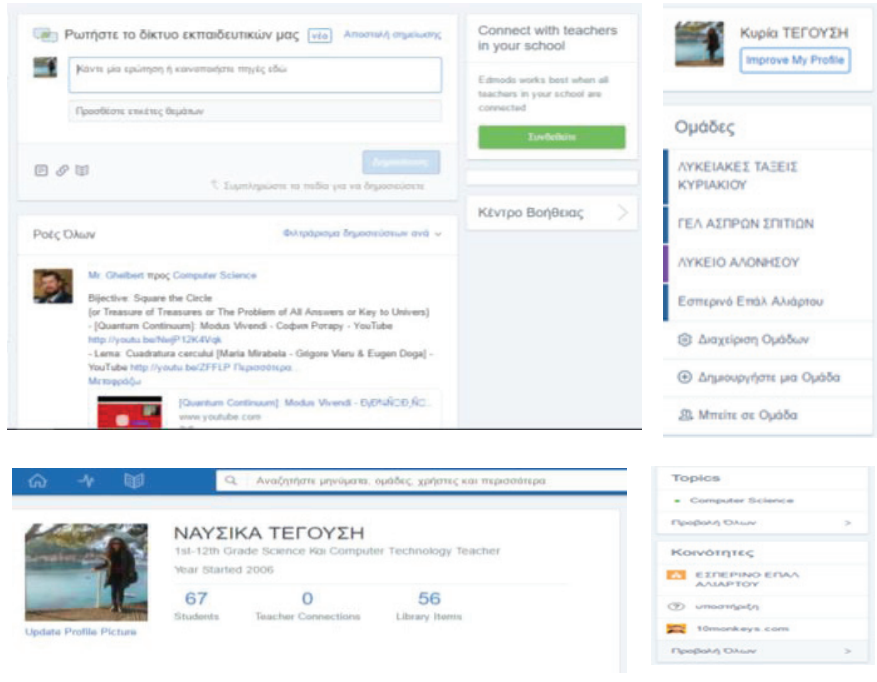

Figure 1: Making our own network.

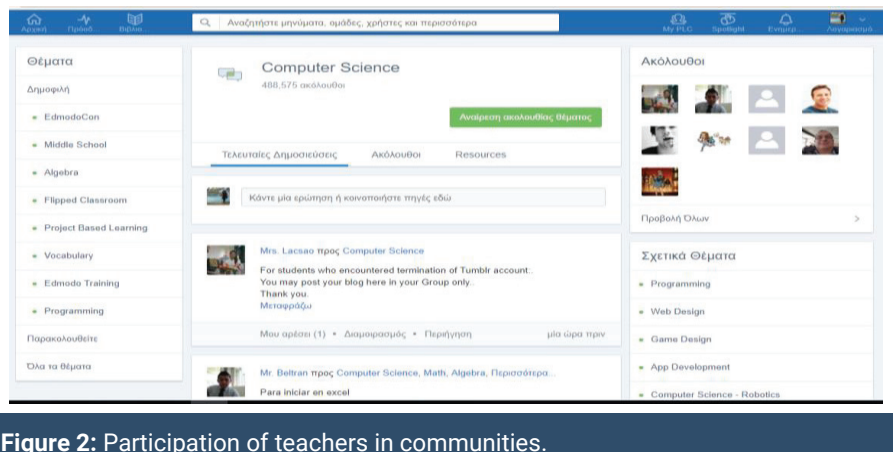

Figure 2: Participation of teachers in communities.

as well as communication, co-ordination and collaboration between the teacher and pupils both inside and outside the classroom, has prompted students' will to work in this way.

\section{The method}

In practice, the procedure followed in an Evening Vocational Lyceum (EPAL) of the Prefecture of Boeotia the school year 2015-2016 for two sections of the A Lyceum, following the demonstration of Edmodo's environment and its potential, was as follows:

\section{Create accounts}

Visit the official Edmodo website. First of all, the teacher was required to register and create an account. Then we moved to the home page and created the group of students with whom we intended to work, giving it the title: Informatics Applications (Figure 3).

Students to access the Edmodo platform I had to use the documents required for my registration and application. In particular, the student gave students for each class or sent them whenever they needed me to access and implement their class (Figure 4).

\section{Create groups}

Two groups of students were created, one for each 


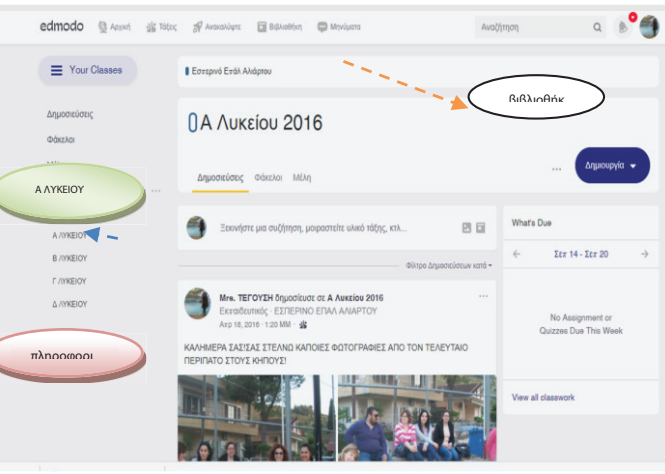

Figure 3: Illustration of groups.

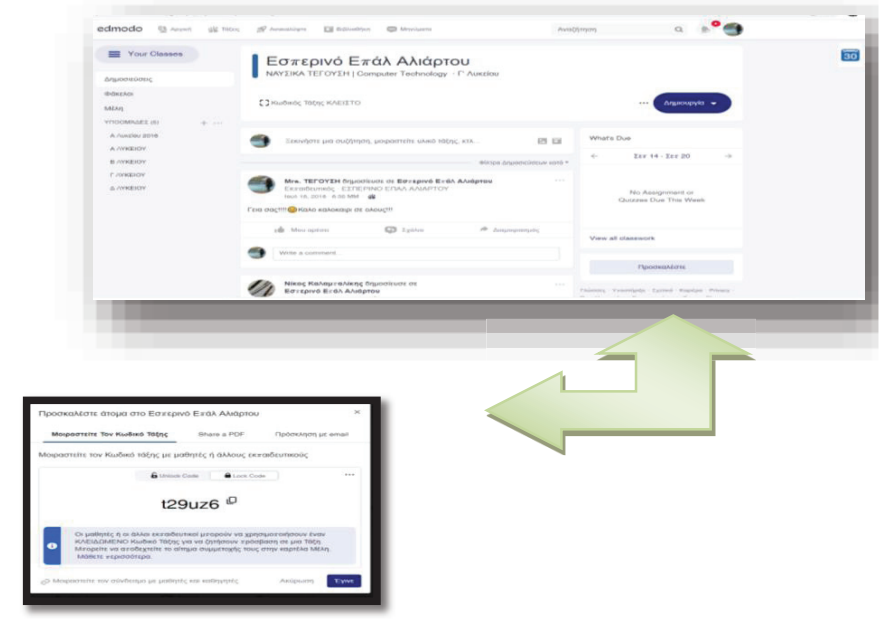

Figure 4: Class groups and group code

department using the class (group) code, all students were enrolled in each department (group), while a note was sent to all groups welcoming them to the network and setting the rules for its use. included a user agreement which prohibited: a) the publication of the registration code of the online class (group), b) the writing of abusive or racist comments and c) the posting of obscene content.

\section{Assignment}

- Initially, we devoted much of our teaching to acquainting and familiarizing students with Edmodo. The teaching method used was to demonstrate the basic concepts using a video projector at the beginning of the lesson. The students watched the demonstration and then they sat in front of their computers' screen to: read a task, open up their teacher's instructions, find resources in the library, and hand in an assignment. Assistance in this phase was only provided when it was considered absolutely necessary (for example, when a group could not continue).

- At the next lesson, a task was assigned to learn to modify their profile, send a new message to their classmates or a personal message to their teacher, upload files, pictures and links to their backpack, and send links through a message. Therefore, an electronic work folder (e-portfolio, where each student and the teacher of the class could refer to the material created throughout the school year) was automatically created.

\section{Inclusion of parents in the network}

Edmodo automatically creates for each student a corresponding parent code, which the parent can use to become a member of the group where their child belongs. In this way, the parent has the ability to monitor the progress of their child and talk with the teacher and other parent groups.

\section{Additional features of edmodo}

Calendar: through the calendar can be planned in the long run, so that the teacher and students can manage their time in the best possible way and have an overall picture of their work. This is how the study modules, the weekly tests, the exercises, the assignments, the competitions were planned.

Messages: enabled the teacher to communicate with the students to send exercises and information, solve questions, clarifications, for direct communication with students, for help, etc.

Quiz: we give it a title, we define how much time students have at their disposal to answer it, the type of questions (right / wrong, short answer, gap filling, matching), the number of questions, the units with which they are evaluated. In the same way we did the work, the exercises and tests and at the same time we kept all of them on file (Figure 5).

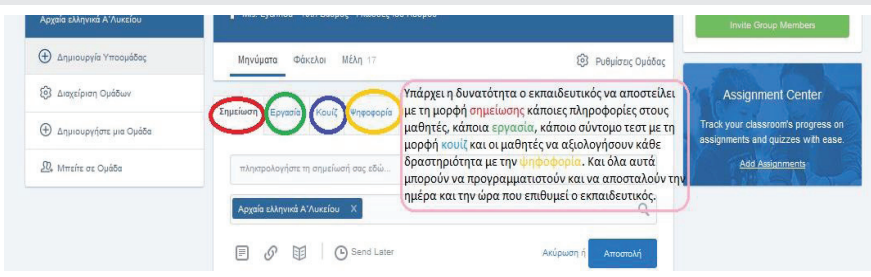

Figure 5: Additional features of Edmodo.

Advantages and disadvantages of using Edmodo in the secondary education

The use of Edmodo has positively influenced the students of the 1st class of Lyceum to:

- Collaborate in and out of class as they could interact online remotely on a common platform. In this way they were able to post laboratory exercises and take the corresponding mark by the teacher.

- Be enthusiastic about their environment, since understanding and managing it was quite similar to another social media tool, such as "Facebook" where all of them had their profile so it was very easy for them to deal with their profile shaping (Avatar and photos) by posting music from the YouTube network and exchanging messages. Although Edmodo has common features with Facebook, the teacher has clarified that 
their differences are big in terms of personal data security and its use in the educational process.

Communicating with each other by exchanging messages, reinforcing the coherence of the class and their group respectively. In particular, during periods of Public or National holidays where there are no lessons (Easter, Christmas, at the weekends).

- Grading and posting the score of daily laboratory activities to award prizes as a way of rewarding classroom real-time assignment by the teacher (Figure $6)$.

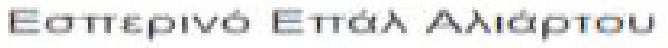
BaGmai Tlaparna 1

\section{Atudents}

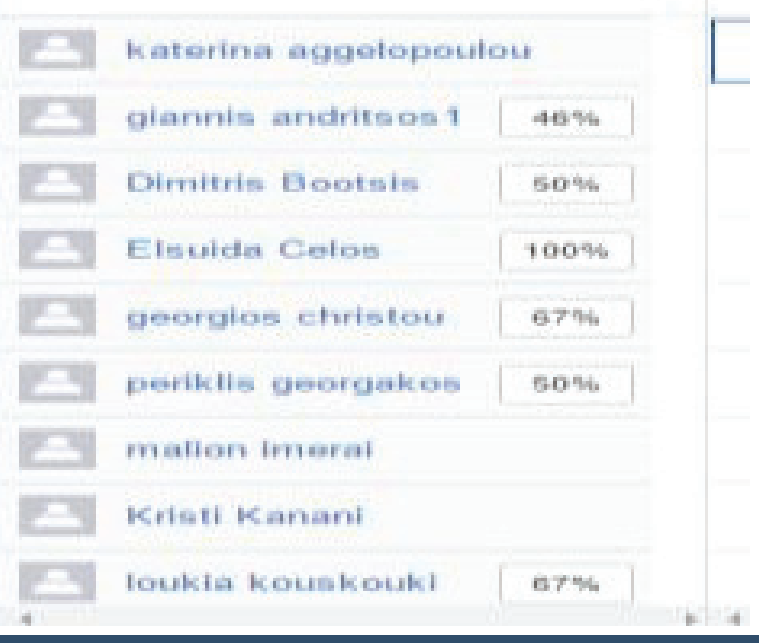

Figure 6: Score of daily laboratory activities.

We can consult the Good Practices Guide on how to use online tools and communities in the field of education and lifelong learning (Learning Project 2.0 plus) and find important references to the practical application of Edmodo in high schools of the country. The presentation of the environment of Edmodo is characterised by normal design, without being extravagant and distracting for users. The organisation is considered quite structured, so that a user regardless of age can easily manage it from the first moment. The sharpness of the text on the screen is very good, whereas their density is also very good. In addition, the navigation in various menus is controlled by icons or titles of links, which show an obvious and simple way of using them. It is also very important the resemblance of the original navigation environment in Edmodo with the equivalent of Facebook. This creates positive and intimate feelings to the users from the beginning and makes the environment suitable for direct interaction with users.
One of the drawbacks we found in Edmodo's use is that students often forget their usage codes to log in the digital classroom. So, until the correct codes or new accounts are detected, problems were created causing a delay in the learning process. Thus, then, duplicates had to be cleansed frequently by the class teacher. Another disadvantage of Edmodo according to the students was the non-use of the "like" function, as well as the blocking of communication (closed network) with external users (friends) [5-14].

\section{Conclusions}

The whole process was successful, so we can summarize the conclusions that come to agree with the conclusions of another survey by teachers $[6,15]$, as shown below:

- Edmodo's work environment caused students' interest as the lesson gained more interest.

- Communication between the teacher and some students continued after the end of the school year as a means of communication and social networking.

- An electronic work folder was created automatically, where each student and class teacher could refer to the material created throughout the school year.

- Parents could be informed at any time about the progress of their children and chat with the teacher through the online platform.

- Students were familiar with Web 2.0 applications learning to use social networking tools in a secure way.

- The environment of Edmodo caused the pupils' intense interest in successfully completing their activities and encouraged their collaboration. The prevailing climate in the classroom was appropriate for active, cooperative learning.

- The electronic form of laboratory activities instead of photocopies saved teacher's time and paper.

- The teacher could prepare and organize his lesson as well as evaluate his students through Edmodo remotely and outside the classroom.

- The environment of Edmondo enables the teacher to create multiple choice or free response questions (e-assessment).

- Discussions take place in designated areas (forum) in the context of groups that have been created.

We could also say that it is a modern, safe and educational useable tool, which can be applied to the requirements of each course and be a reference point for the Organisation of any learning activity. The fact also that available completely free, makes it undoubtedly attractive to teachers, so you choose to use and integrate into this also students and parents. Nevertheless, as with any educational software, Edmodo, can be used as a supplementary means of instruction, which will enhance rather than replace the role of education, in order to contribute to students' self-motivation and eventually 
to achieve pedagogical, didactic and learning goals of the curriculum and instructional program. Finally, Edmodo helps teachers make a classroom community [16-21].

The results of another teachers' survey [8] have shown that teachers use Edmodo because they consider it interesting and safe as an environment, it motivates students in the learning process and wish to renew their teaching practices. They use it to upload information, lesson notes (Figure 7), contests, quizzes (Figure 8, Figure 9), as a means of exchanging views and communication among students or as project promoters and implementing European projects, while others have used it to organize an argument competition. Its advantages are its communicative and cooperative potential, its interactive features, its attractive and safe environment for students, as well as its ability to personalise their teaching.

However, they believe it is a disadvantage that they cannot

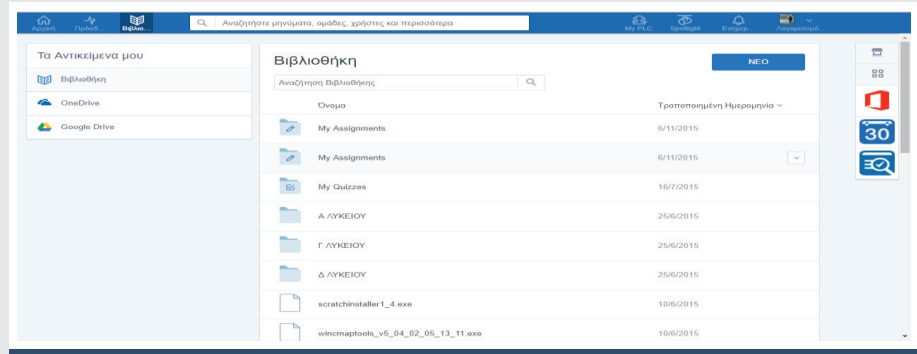

Figure 7: Notes from the Student Assignment Library.

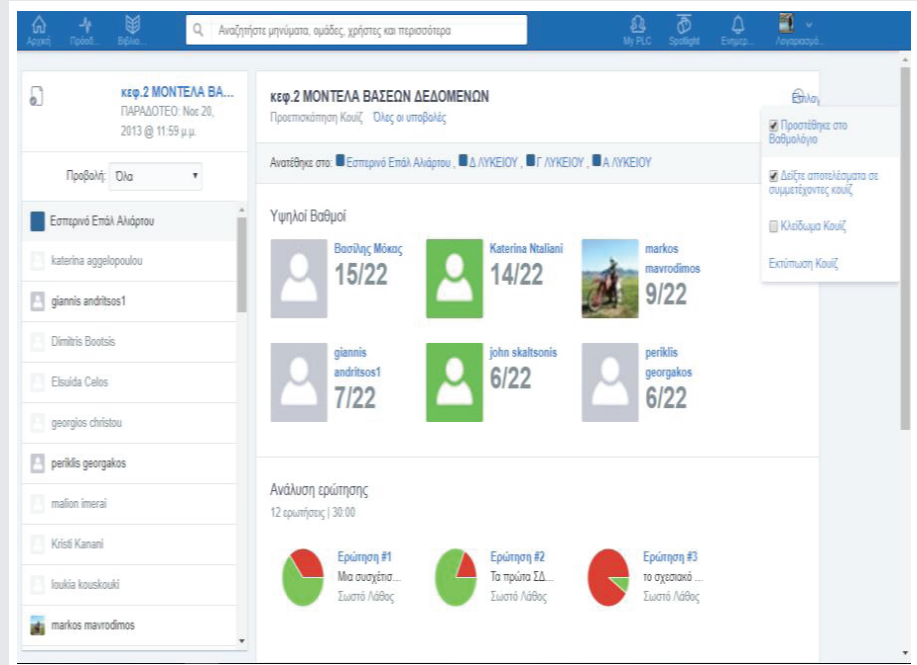

Figure 8: Questions quiz evaluation results.

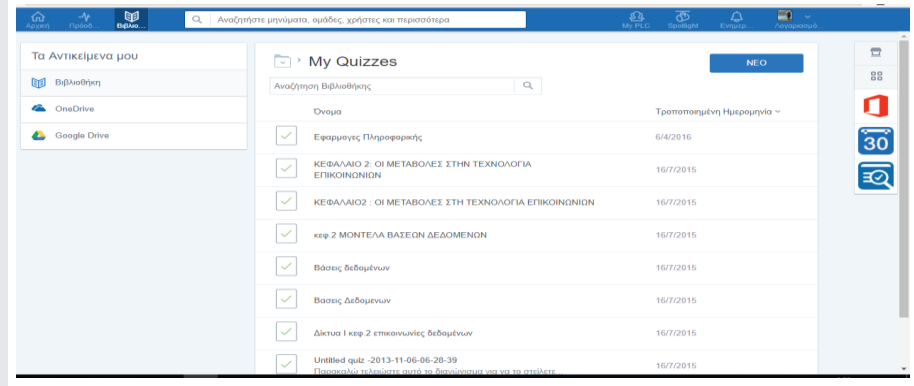

Figure 9: Set of teacher quizzes to students. develop larger texts on the posts or the fact that they lose time when students forget their passwords. They are also disappointed with the attitude of their colleagues, who consider that it is not a lesson but a simple game [21-26].

\section{Future extensions}

It is strongly recommended to use it in the teaching the "Informatics Applications" course in the First Class of General and Evening Vocational Lyceum (EPAL), especially if the children are familiar with other social networking environments such as "Facebook" in previous years. Edmodo is also a powerful online tool for communicating with the interior or exterior of the class every day and even the days of Public or National holidays, motivating them to combine education and fun in a safe environment.

The process of learning in groups has a positive effect on the participants. In the context of a group the individual controls his learning within an organised collective framework (Selfregulated learning) [9,27-37] by using the tools provided by the Internet and especially through social networks with online (OSN) and develops communication and cooperation.

In the future we intend to measure whether such a teaching approach influences pupils' performance in the classroom, if the teacher was also associated with other groups of teachers and pupils inside and outside our country and cultivate student's learning autonomy of cognitive and metacognitive development. Researchers, according to the survey of the teachers mentioned above [8], consider that it would be very interesting to investigate students' opinion on this tool, because their own view based on their preferences can, on the one hand [30-35], to contribute to the planning of activities that trigger them more, and secondly to give ideas for teachers to adopt such techniques and methods that the particular tool could make a difference in the learning of school classes of today.

\section{References}

1. Glezou K, Grigoriadou M (2010) Greek Online Educational Social Networks. In Koltsakis V, Salonikidis I, Dodontsis M (Eds.), Proceedings of 2nd Panhellenic Conference of Imathia. Digital and Network Applications in Education. Beroea-Naousa, April 23-25, 1665-1677. Link: https://www.ekped.gr/praktika10/web/149.pdf (in Greek).

2. Balasubramanian K, Jaykumar V, Fukey LN (2014) A study on "Student preference towards the use of Edmodo as a learning platform to create responsible learning environment". Procedia - Social and Behavioral Sciences 144: 416-422. Link: https://bit.ly/2HEQkuh

3. Light D, Polin DK (2010) Integrating Web 2.0 tools into the classroom: Changing the culture of learning. New York: EDC Center for Children and Technology. Link: https://bit.ly/2UPOWbt

4. Holland C, Muilenburg L (2011) Supporting Student Collaboration: Edmodo in the Classroom. In Koehler M, Mishra P (Eds.), Proceedings of Society for Information Technology \& Teacher Education International Conference. Chesapeake, VA: AACE 3232-3236. Link: https://bit.ly/33fYG3U

5. Kapaniaris A, Liovas D, Neochoritou D (2012) A secure Social Learning Network for Teachers \& Students (Edmodo): teaching in secondary and tertiary education. In Karagiannidis Ch., Politis P, Karasavvidis I (Eds.), Proceedings 
of the 8th Panhellenic Conference with International Participation 'ICT in Education', University of Thessaly, Volos, September 28-30 (in Greek). Link: http://bit.ly/3aozagK

6. Kapaniaris AG, Papadimitriou EM (2012b) Information Literacy in the New Digital School. Thessaloniki: Ziti Publications (in Greek).

7. Vamvakousi M, Ziveldis A (2013) ICT teaching in elementary school through social networking platform. The case of Edmodo. Proceedings of the 5th Conference on Informatics in Education (CIE 2013), University of Piraeus, Piraeus, October 11-13. (in Greek).

8. Batsila M, Tsihouridis Ch (2014) The use of Edmodo, as a tool to enhance students' skills. A case study. In Samara Th, Kousloglou E, Salonikidis I, Tzimopoulos N (Eds.) Proceedings of the 3rd Panhellenic Educational Conference of Imathia: "Utilisation of ICT in the in teaching practice", Naousa, April 4-6, 152-160 (in Greek). Link: https://bit.ly/3mu7MAB

9. Pange J (2009) Educational Technology. Ioannina, Theodoridis publications (in Greek).

10. Boyd DM, Ellison NB (2007) Social network sites: Definition, History and Scholarship. Journal of Computer - Mediated Communication 13(1): 210-230. Link: https://bit.ly/2J4g1Wn

11. Brady KP, Holcomb LB, Smith BV (2010) The use of alternative social networking sites in higher education settings: A case study of the e - learning benefits of Ning in education. Journal of Interactive Online 9: 151-170. Link: https://bit.ly/36gXqPQ

12. Carrol JM, Rosson MB, Convertino G, Ganoe CH (2006) Awareness \& Teamwork in computer-supported collaborations. Interacting with Computers 18(1): 21-46. Link: https://bit.ly/2S7uh1s

13. Debatin B, Lovejoy JP, Horn A-K, Hughes BN (2009) Facebook and online privacy: Attitudes, behaviors and unintended consequences Journal of Computer - Mediated Communication 15(1): 83-108. Link: https://bit.ly/2Sdo2ct

14. De Longueville B (2010) Community-based geoportals: The next generation? Concepts and methods for the geospatial Web 2.0. Computers, Environment \& Urban Systems 34(1): 299-308. Link: https://bit.ly/34eowVr

15. Fardoun HM, Alghazzawi DM, López SR, Penichet VMR, Gallud JA (2012) Online Social Networks Impact in Secondary Education. In: Vittorini P. Gennari R., Marenzi I., de la Prieta F., Rodríguez J. (eds) International Workshop on Evidence-Based Technology Enhanced Learning. Advances in Intelligent and Soft Computing, vol 152. Springer, Berlin, Heidelberg. Link: https://bit.ly/33c8PP0

16. Herrington J, Kervin L (2007) Authentic learning supported by technology: Ten suggestions and cases of integration in classrooms. Educational Media International 44(3): 219-236. Link: https://bit.ly/2WtUnOd

17. Newby JT, Stepich AD, Lehman DJ, Russell DJ, (2009) Educational Technology in Teaching and Learning, Epikentro, Thessalonica (in Greek).

18. Anastasiades P (2004) ICT and Collaborative Creativity in Modern School, In Anastasiades $\mathrm{P}$, Zaranis N, Oikonomidis V, Calogiannakis M (Eds.), $9^{\text {th }}$ Panhellenic Conference with International Participation "Information \& Communication Technology in Education”, Rethymnon, October 3-5 (in Greek).

19. Argyri V (2014) The use of Edmodo in Greek schools. Master Thesis, Larisa (in Greek).

20. Glezou K, Grigoriadou M, Konstantinou N (2010) Utilisation of online social networking services in Greek education. In Grigoriadou M. (Ed.) Proceedings of the 5th Panhellenic Conference "Didactics of Informatics" Athens 375-384 (in Greek).

21. Goutas T (2012) Edmodo: A secure social networking \& e-learning site, In Alexandris N, Vlamos P, Douligeris Ch., Belesiotis VS, Proceedings of the 4th Conference on Informatics in Education, October 5-7, 622-629 (in Greek). Link: https://bit.ly/3nL4jyz
22. Kahrimanis G, Komis V, Avouris N (2008) Methodologies for analyzing cooperation. In Avouris N, Karagiannidis Ch, Komis V (Eds.), Collaborative Technology, Systems, and Collaborative models for homework, learning, practice communities and knowledge creation. Athens: Kleidarithmos 179182 (in Greek).

23. Lekka AM, Sypsas A, Pange J (2013) Social networks and mlearning: the case of edmodo. $7^{\text {th }}$ International Conference in Open \& Distance Learning November 2013, Athens, Greece. (in Greek).

24. Lychnou E (2017) The use of Edmodo as a tutoring method of Ancient Greek in the 1st year of Lyceum. Open Education: The Journal for Open and Distance Education and Educational Technology 13(1): 76-87. (in Greek). Link: https://bit.ly/3igQKUc

25. Melidou E, Avgerinou MD (2013) Utilization and usability of online learning communities in the learning process. In Lionarakis A (Ed.), 7th International Conference on Open and Distance Education. Learning Methodologies. Athens: Publications of the Hellenic Open \& Distance Network Education 126141. November 8-10. (in Greek)

26. Milinis S (2012) Educational Social Network Edmodo in Teaching Practice, Information Project "Learning 2.0 Plus", White Paper - Youth Initiatives and Good practices for the utilisation of Internet Tools and Communities in the field Of Education and Lifelong Learning. In Meimaris M, Gouskos D, (Eds.) Athens: Research University Institute of Applied Communication of the University of Athens 535-541. (in Greek). Link: https://bit.ly/348caxP.

27. Paraskevopoulos IN (2004) Creative thinking at school and in the family. Athens, Hellenic Letters Publications.

28. Stivaktaki M (2012) Social networking platforms in the modern school. In 6th Panhellenic Conference on Informatics in Education. Florina, April 20-22, 401 406 (in Greek). Link: https://bit.ly/3nlbSpA

29. Sotiriadou A, Papadakis S (2013) The utilisation and limitations of Social Networks For Teaching Informatics in Secondary Education. Proceedings of the 7th Panhellenic Conference of Informatics Teachers, Thessalonica, April 12-13 (in Greek). Link: https://bit.ly/3kZkPJY

30. Vassala P (2005) Distance school education. In Lionarakis A, Giosos I, Koutsouba M, Vassala P, Panagiotakopoulos Ch, Xenos M (Eds.), Open and Distance education, Pedagogical and Technological Applications (pp. 53-80). Patras: EAP (in Greek).

31. Xyla $E$ (2014) The use of Edmodo in the language course of the $1^{\text {st }}$ Gymnasium, a case of an online digital classroom, Proceedings of the 3rd Panhellenic Educational Conference of Imathia, "Utilisation of Information and Communication Technology in teaching practice 153-161. April 4-6, (in Greek).

32. Yfantis H (2016) Asynchronous support (Moodle and simple mobile apps) to students of Evening Lyceums for the courses of Panhellenic exams. In Salonikidis I, (Ed.), Utilisation of Information and Communication Technology in teaching Practice Volume III (pp. 299-305). Panhellenic Association of Teachers for Utilisation of ICT In the Natural Sciences "Michalis Dertouzos". Thessalonica, April 8-10 (in Greek). Link: http://4syn-thess2016.ekped.gr/wpcontent/uploads/2016/04/V3.pdf

33. Giakoumakis EA, Gyrtis K, Belesiotis VS, Xinos P, Stergiopoulou-Kalantzi N (2000) Computer Informatics Applications, $1^{\text {st }}, 2^{\text {nd }}$ and $3^{\text {rd }}$ Unified Lyceum, Athens: School Book Publishing Organisation (OEDB) (in Greek).

34. Piperidou Eirene (2019). Differentiated instruction in mathematics in a mixed elementary school classroom using the Edmodo digital environment (Master's Thesis, University of Piraeus, Piraeus, Greece) (in Greek). Link: https://bit.ly/338qE1d

35. Thongmak, M. (2013). Social Network System in Classroom: Antecedents of Edmodo. Journal of e-Learning and Higher Education. DOI: 10.5171/2013.657749. Link: https://bit.ly/2J0uUIL 
36. Karipidis N (2015) Introduction to the digital classroom with the Edmodo online tool. Proceedings of the 9th Panhellenic Conference of Informatics Teachers, Kastoria, April 24-26 (in Greek). Link: https://bit.ly/3fqPFcJ
37. Sotirudas V, Garitsis I, Koundouros M, (2013). Collaborative teaching of computer science in primary education. The case of the Edmodo e-learning community. Proceedings of the 7th Panhellenic Conference of Informatics Teachers, Thessalonica, April 12-13 (in Greek). Link: https://bit.ly/3a6Qvcz
Discover a bigger Impact and Visibility of your article publication with

Peertechz Publications

\section{Highlights}

* Signatory publisher of ORCID

* Signatory Publisher of DORA (San Francisco Declaration on Research Assessment)

* Articles archived in worlds' renowned service providers such as Portico, CNKI, AGRIS, TDNet, Base (Bielefeld University Library), CrossRef, Scilit, J-Gate etc.

* Journals indexed in ICMJE, SHERPA/ROMEO, Google Scholar etc.

* OAI-PMH (Open Archives Initiative Protocol for Metadata Harvesting)

* Dedicated Editorial Board for every journa

* Accurate and rapid peer-review process

* Increased citations of published articles through promotions

* Reduced timeline for article publication

\section{Submit your articles and experience a new surge in publication services}

(https://www.peertechz.com/submission).

Peertechz journals wishes everlasting success in your every endeavours.

Copyright: @ 2020 Tegousi N, et al. This is an open-access article distributed under the terms of the Creative Commons Attribution License, which permits unrestricted use distribution, and reproduction in any medium, provided the original author and source are credited. 